\title{
DIAGNOSIS OF BACTERIAL VAGINOSIS IN REPRODUCTIVE AGE GROUP IN TERTIARY HEALTH CARE HOSPITAL IN SOUTH INDIA: COMPARISION OF CLINICAL AND MICROBIOLOGICAL CRITERIA
}

\author{
K. Pavani1 ${ }^{1}$ K. Saileela ${ }^{2}$
}

HOW TO CITE THIS ARTICLE:

K Pavani, K Saileela. "Diagnosis of bacterial vaginosis in reproductive age group in tertiary health care hospital in south India: Comparison of clinical and microbiological criteria". Journal of Evolution of Medical and Dental Sciences 2013; Vol2, Issue 35, September 2; Page: 6611-6615.

ABSTRACT: BACKGROUND/AIMS: Bacterial vaginosis is of special public health concern in India because of high burden of reproductive and pregnancy related morbidity. Early diagnosis and treatment might be useful in prevention of complications and can only be achieved by accurate, reproducible and inexpensive method. The purpose of the present study was to estimate the prevalence of Bacterial Vaginosis in rural setup and to compare the diagnostic accuracy of Amsel's criteria and Culture with Nugent's scoring system in diagnosis of Bacterial Vaginosis (BV). MATERIALS AND METHODS: Two high vaginal swabs were collected from posterior fornix of women aged 18-45yrs complaining of abnormal vaginal discharge under aseptic precautions and were subjected to direct microscopy and culture. RESULTS: The present study included 204 cases of abnormal vaginal discharge. In comparison with Nugent's criteria the sensitivity, specificity, positive predictive value and negative predictive value of Amsel's criteria were $78.72 \%, 92.35 \%, 75.51 \%$ and 93.54\%. The culture was $42.55 \%$ sensitive and $92.99 \%$ specific, the positive predictive value was $64.51 \%$ and the negative predictive value was $84.39 \%$. We diagnosed Bacterial vaginosis in $47 / 204$ (23.03\%) cases by Nugent's method, 49/204 (24.01\%) cases by Amsel's criteria and in 31/204 (15.91\%) cases by culture.

KEY WORDS: Bacterial vaginosis, Amsel's criteria, Nugent scoring.

INTRODUCTION: Bacterial vaginosis is a condition characterised by raised vaginal $\mathrm{pH}$ and milky discharge in which normal vaginal flora is replaced by mixed flora of aerobic, anaerobic and microaerophilic species ${ }^{1}$. The microbiology of bacterial vaginosis is complex and involves various organisms which include facultative anaerobes such as Gardnerella vaginalis, Mycoplasma hominis, anaerobes such as Mobiluncus, Bacteroides, Prevotella, Pepto streptococci, Eubacterium². The term vaginosis is used instead of vaginitis for this condition because there is no inflammatory response in vagina. It is associated with infertility, low birth weight infants, late miscarriage, chorioamnionitis and postpartum endometritis. Women with bacterial vaginosis are more likely to be co-infected with Herpes simplex virus type-2, Trichomonas vaginalis, Neisseria gonorrhoeae and HIV3. The clinical manifestations vary from asymptomatic state to increased homogenous grayish white vaginal discharge, pruritis, lower abdominal pain, pain during coitus etc. The purpose of the present study was to estimate the prevalence of Bacterial Vaginosis in rural setup and to compare the diagnostic accuracy of Amsel's criteria and Culture with Nugent's scoring system in diagnosis of Bacterial Vaginosis. 
MATERIALS AND METHODS: It is a prospective study carried out by Microbiology and Gynaecology departments in Kamineni institute of medical sciences, Narketpally, Nalgonda over a period of two years from January 2009 to 2011. A total number of 204 female patients of reproductive age group attending Gynaecology outpatient department with chief complaints of abnormal vaginal discharge were included in this study. Exclusion criteria included vaginal bleeding, pregnancy, vaginal or cervical mass and patients on antibiotics. Two high vaginal swabs were collected from posterior fornix under aseptic precautions and transported immediately to Microbiology laboratory. While taking the swab character of vaginal discharge was observed. The $\mathrm{pH}$ of vaginal discharge was recorded using standard $\mathrm{pH}$ indicator paper with range 1 to 14 . The amine test was performed by adding few drops of $10 \% \mathrm{KOH}$ (potassium hydroxide) solution directly over vaginal secretions smeared on glass slide to find out if there was emission of amine like odour. The wet preparation was assessed for presence of clue cells, motile trophozoites of Trichomonas vaginalis and budding yeast cells. Clue cells were identified as squamous epithelial cells with bacilli adherent to surface obscuring the cell margin. The diagnosis of Bacterial Vaginosis was done by using Amsel's criteria ${ }^{4}$ which encompasses fulfilling three of the following four criteria: presence of homogeneous vaginal discharge, $\mathrm{pH}>4.5$, positive amine odor test, and presence of clue cells on vaginal wet smear ${ }^{5}$. Gram stain smears were read for morphotyping and scoring patterns according to Nugent's ${ }^{6}$ scoring as in Table 1.

Table-1: Scoring system of Gram stained smears (Nugent et al) ${ }^{6}$

\begin{tabular}{|l|c|c|c|}
\hline $\begin{array}{l}\text { Bacterial } \\
\text { morphotype }\end{array}$ & $\begin{array}{c}0-3 \\
\text { (normal) }\end{array}$ & $\begin{array}{c}4-6 \\
\text { (intermediate) }\end{array}$ & $\begin{array}{c}7-10 \\
\text { (Bacterial Vaginosis) }\end{array}$ \\
\hline Lactobacilli & $4+$ to $3+$ & $2+$ to $1+$ & 0 \\
\hline $\begin{array}{l}\text { Gardnerella } \\
\text { vaginalis and } \\
\text { Bacteroides }\end{array}$ & 0 to 1+ & $2+$ to $3+$ & $>4+$ \\
\hline $\begin{array}{l}\text { Mobiluncus } \\
\text { curved Gram } \\
\text { variable bacilli) }\end{array}$ & Nil & Nil & $1+$ to 4+ \\
\hline Clue cells & Nil & Nil & present \\
\hline
\end{tabular}

Average number of morphotypes seen per oil immersion field: $0=\mathrm{Nil}, 1+=1,2+=2$ to $4,3+=$ $5-30,4+=>30$.

Culture for Gardenerella and anaerobes was done on freshly prepared blood agar with hemin and vitamin $\mathrm{K}$ supplement. The plates were incubated at $37^{\circ} \mathrm{C}$ in $5-10 \%$ carbon dioxide for Gardenerella and in anaerobic jar (Dynamicro) for anaerobes. The colonies were identified by standard methods $7,8,9$.

RESULTS: Out of 204 vaginal samples collected, 68.62\% (140/204) were from patients more than 25 years and $31.37 \%$ (64/204) were from patients below 25 years. BV was diagnosed in 24.01\% 


\section{ORIGINAL ARTICLE}

(49/204) of the patients using clinical composite criteria as suggested by Amsel, in $23.03 \%$ $(47 / 204)$ of the patients using Nugent scoring and in $15.19 \%(31 / 204)$ of the patients by culture. The Bacterial vaginosis culture isolates in present study are Gardnerella vaginalis, Pepto streptococci spp., Prevotella and Bacteroides spp.

In comparison with Nugent's criteria, the sensitivity, specificity, positive predictive value and negative predictive value of Amsel's criteria were $78.72 \%, 92.35 \%, 75.51 \%$ and $93.54 \%$. The culture was $42.55 \%$ sensitive and $92.99 \%$ specific, the positive predictive value was $64.51 \%$ and the negative predictive value was $84.39 \%$. Statistical analysis showed that all three methods could be used as a means for the diagnosis of Bacterial vaginosis $(\mathrm{p}<0.01)$.

Table -2: Comparison of diagnosis of Bacterial Vaginosis by Amsel's criteria and culture with Nugents scoring as gold standard.

\begin{tabular}{|c|c|c|c|c|c|}
\hline \multirow{2}{*}{\multicolumn{2}{|c|}{ Methods of diagnosis }} & \multicolumn{3}{|c|}{ Diagnosis of BV by Nugents scoring } & \multirow[b]{2}{*}{ P-value } \\
\hline & & \multirow{2}{*}{$\begin{array}{c}\begin{array}{c}\text { Nugents } \\
\text { score }>7 \\
\mathbf{n}=47\end{array} \\
37 \\
\end{array}$} & \multirow{2}{*}{$\begin{array}{c}\begin{array}{c}\text { Nugents } \\
\text { score 0-6 } \\
n=157\end{array} \\
12 \\
\end{array}$} & \multirow{2}{*}{$\begin{array}{c}\begin{array}{c}\text { Total } \\
\mathrm{n}=204\end{array} \\
49\end{array}$} & \\
\hline \multirow{2}{*}{ Amsels criteria } & Bacterial vaginosis & & & & \multirow{2}{*}{$<0.01$} \\
\hline & Normal & 10 & 145 & 155 & \\
\hline \multirow{2}{*}{ Culture } & Bacterial vaginosis & 20 & 11 & 31 & \multirow{2}{*}{$<0.01$} \\
\hline & normal & 27 & 146 & 173 & \\
\hline
\end{tabular}

DISCUSSION: Among the laboratory methods for the diagnosis of bacterial vaginosis, Gram-stained vaginal smears are the least expensive, require the least time to perform, and are more widely available than other laboratory methods ${ }^{10}$. In the present study we compared Amsel's criteria and Culture with Nugent's method for the diagnosis of bacterial vaginosis. The Nugent scoring system was used as the reference method as this is regarded as the "gold" standard. The present study included patients based on symptomatology and showed the prevalence of Bacterial vaginosis as $24.01 \%$ by Amsel's criteria, $23.03 \%$ by Nugent scoring and $15.19 \%$ by culture.

In the present study, Amsel's method was found to be $78.72 \%$ sensitive and $92.35 \%$ specific as compared to Nugent's method. Previous studies have shown that the diagnosis of Bacterial vaginosis by Amsel's criteria was less sensitive than the gram stain interpretation ${ }^{11}$. The Culture was found to be $42.55 \%$ sensitive and $92.99 \%$ specific compared to Nugent's method. Culture is the gold standard method for diagnosis of most of the bacterial diseases; however, culture cannot become the gold standard for diagnosis of Bacterial vaginosis as the organisms which are involved in Bacterial vaginosis cannot be isolated in the laboratory easily and as normal women also have this flora in their vagina in small numbers.

The rate of bacterial vaginosis, when diagnosed by Nugent's scoring system, was $23.03 \%$. Indian studies which were conducted on the general population, have shown a similar prevalence ${ }^{3,}$ 12.

CONCLUSION: Amsel's criteria were comparable with Nugent's criteria for the diagnosis of bacterial vaginosis. Diagnosis of bacterial vaginosis by culture was least sensitive method. 


\section{ORIGINAL ARTICLE}

\section{REFERENCES:}

1. Aggarwal A, Devi p, Jain R. Anaerobes in bacterial vaginosis. Indian J of Med Microbiol 2003; 21: 124-126.

2. Sumati A.H., Saritha N.K. Bacterial vaginosis with special reference to anaerobes. Indian J of Pathol Microbiol 2009; 52: 56-7.

3. Madhivanan P, Krupp K, Chandrasekaran V, Karat C, Arun A, Cohen CR, et al. Prevalence and correlates of Bacterial vaginosis among young of reproductive age in Mysore. Indian J Med Microbiology. 2008; 26: 132-7.

4. Amsel R, Totten PA, Spiegel CA, Chen KCS, Eschenbach D, Holmes KK. Non-specific vaginitis. Diagnostic and microbial and epidemiological associations. Am J Med 1983; 74: 14-22.

5. Eschenbach DA, Hillier S, Critchlow C, Stevens C, DeRouen T, Holmes KK. Diagnosis and clinical manifestations of bacterial vaginosis. Am J Obstet Gynaecol 1988; 158: 819-28.

6. Nugent RP, Krohn MA, Hillier SL. Reliability of diagnosis of BV is improved by standardised method of Gram stain interpretation. J Clin Microbiol 1991; 29(2): 297-301.

7. Brown R, Collee JG, Parton IR. Bacteroides, Fusobacterium and other Gram negative anaerobic rods; Anaerobic cocci; identification of anaerobes. In: Collee JG, Fraser AG, Marimon BP, Simmons A, editors. Mackie of McCartney Practical Medical Microbiology. 14th edition. New York: Churchill Living Stone Inc: 1996. p. 501-520.

8. Betty AF, Daniel FS, Alice SW. Non branching catalase negative, gram positive bacilli. In Bailey and Scott's Diagnostic Microbiology, 12th ed. Betty AF, Daniel FS, Alice SW (eds) St. Louis, Missouri: Mosby Elsevier. 2007; pp 305-6.

9. Betty AF, Daniel FS, Alice SW. Laboratory considerations. In Bailey and Scott's Diagnostic Microbiology, 12th ed. Betty AF, Daniel FS, Alice SW (eds) St. Louis, Missouri: Morby Elsevier 2007;pp 463-77.

10.Nugent RP, Krohn MA, Hillier SL. Reliability of diagnosing bacterial vaginosis is improved by a standardized method of Gram stain interpretation. J Clin Microbiol 1991; 29:297-301.

11.Beverly ES, Hua YC, Qiong JW, Zariffard MR, Mardge HC, Gregory TS. Utility of Amsel's Criteria, Nugent's Score, and quantitative PCR for Gardnerella vaginalis, Mycoplasma hominis, and Lactobacillus spp. for the diagnosis of bacterial vaginosis in human immunodeficiency virus-infected women. J Clin Microbiol 2005; 43:4607-12.

12. Rao PS, Devi S, Shriyan A, Rajaram M, Jagdishchandra K. Diagnosis of bacterial vaginosis in a rural set up: comparison of the clinical algorithm, smear scoring and culture by using a semiquantitative technique. Indian J Med Microbiol 2004; 22(1):47-50. 


\section{ORIGINAL ARTICLE}

\section{AUTHORS:}

1. K. Pavani

2. K. Saileela

\section{PARTICULARS OF CONTRIBUTORS:}

1. Assistant Professor, Department of Microbiology, Apollo Institute of Medical Sciences and Research, Jubilee Hills, Hyderabad, A.P. India.

2. H.O.D \& Professor, Department of Microbiology, Kamineni Institute of Medical Sciences, Narketpally, Nalgonda, A.P. India.

\section{NAME ADDRESS EMAIL ID OF THE} CORRESPONDING AUTHOR:

Dr. K. Pavani,

Plot No. 18 \& 19,

Margadarshi Housing Society,

Rasoolpura, Secunderabad - 500003,

A.P., India.

Email- pavanikalagara@gmail.com

Date of Submission: 02/08/2013.

Date of Peer Review: 03/08/2013.

Date of Acceptance: 18/08/2013.

Date of Publishing: 27/08/2013 